ISSN 2738-9898 (Print) ISSN 2738-9901 (Online)

\title{
Seismic Fragility Analysis of Institutional Building of Pokhara University
}

\author{
Narayan Ghimire ${ }^{1}$, Hemchandra Chaulagain ${ }^{2}$ \\ ${ }^{1}$ Post Graduate Student, MSc. in Structural Engineering, School of Engineering, Pokhara University, Pokhara, Nepal. \\ ${ }^{2}$ Assistant Professor, School of Engineering, Pokhara University, Pokhara, Nepal
}

E-mail: hchaulagain@pu.edu.np

Received on: $29^{\text {th }}$ May., 2020

Accepted for publication: 30th Oct., 2020

\begin{abstract}
Fragility curves are derived from fragility function that indicates the probability of damage of structure due to earthquake as a function of ground motion parameter. It helps to predict the level of structural damage and consequently reduce the seismic risk in specific ground motion. In this scenario, this study is focused on the construction of fragility curve of institutional reinforced concrete (RC) building of Pokhara University. For this, the building of School of Health and Allied Science (SHAS) is considered as a guiding case study. For the numerical analysis, the study building blocks are modelled in finite element-based software. The non-linear static and linear dynamic analyses are employed for numerical analysis. In dynamic analysis, building models are subjected to the synthetic accelerograms of the 2015 Gorkha earthquake. Based on the analyses, the analytical fragility curves are plotted in terms of probability of failure at every $0.1 \mathrm{~g}$ interval of peak ground acceleration (PGA) with log normal distribution. Finally, the results are highlighted for different seismic performance level in buildings: slight damage, moderate damage, extensive damage and complete damage for the earthquake of 475 years return period.
\end{abstract}

Keywords: Non-linear analysis, Fragility function, Seismic performance, Reinforced concrete building

\section{Introduction:}

Nepal is located in the Himalayan region which has a long history of moderate to strong seismic events. The main cause of earthquake in the Himalayan belt in due to the collision between Indian and Eurasian plate $[1,2]$. Pokhara valley is located near the main central thrust, that one of the most active fault which caused the repeated powerful earthquakes on past. Geological variation, terrain characteristics, urbanization of city area, low construction materials and technics as well as age of buildings in Pokhara valley are prime causes of structural vulnerability, lead to dead of people and loss of economy [3].

Initially, the institutional buildings in Nepal were constructed with adobe, brick masonry, stone masonry, composite masonry, and timber frame structures. After the increasing maturity of education system as well as construction industries in Nepal, RC building construction has started from late 1970s [4]. Currently, institutional buildings like adobe, brick masonry, stone masonry and timber are replaced by reinforced concrete construction. In the past, most of the buildings face several major earthquakes in the year of 1988, 2011 and 2015. After these major earthquakes, many institutional buildings were 
functional without assessing any seismic evaluation. This might be a prime concern for future catastrophic.

Researchers highlighted the damages of institutional buildings which leads large number of casualties and economic loss in their study [57]. Miyamoto et al., [5] highlighted the damage and collapse of school building in Indonesia due to Sumatra earthquake. Augenti et al., [6] discussed damage and collapse of school building in Italy. In china, Sichuan earthquake damaged the thousands of buildings and injured millions of students [5]. More than 6,000 school building were damaged that lead 17,000 students and 900 teachers died by 2005 and 2008 earthquake in Pakistan [7]. The 2015 Gorkha earthquake in Nepal damaged more than 8200 institutional buildings and an estimated loss of nearly 285 million US dollar [4, 8]. Most of the school/ institutional building in Nepal have shown lack of engineered design, lack of ductile detailing, structural deficiencies and low construction materials and techniques $[4,9-10]$. These are the prime reasons which magnifies the importance to identify the performance level of institutional existing buildings that could be used in future explores to assure life safety during seismic events.

In this context, this research focused on to study the behavior of institutional buildings under the effect of ground motions. The study identifies the status of damage grade: slight damage, moderate damage, extensive damage and complete damage of institutional building in synthetic earthquake. In fact, seismic risk analysis of existing institutional building is necessary to identify seismic vulnerability level under the effect of potential earthquake $[11,12]$. It is achieved through numerical analysis. The building blocks are modelled in finite element-based software.

The non-linear static and linear dynamic analyses are employed for numerical analysis. In dynamic analysis, building models are subjected to the synthetic accelerograms of the 2015 Gorkha earthquake. Based on the analyses, the analytical fragility curves are plotted in terms of probability of failure at every $0.1 \mathrm{~g}$ interval of peak ground acceleration (PGA) with log normal distribution assumption. The results are highlighted for

N. Ghimire and H. Chaulagain different seismic performance level in buildings for the earthquake of 475 years return period.

\section{Numerical Modelling of Structure:}

In this study, one of the school building of Pokhara University (School of Health and Allied Science, SHAS) was considered as a study institutional building. The building consists of three blocks. The building blocks model for numerical analysis was created and analyzed by ETABS software [13]. The software provided reliable result of linear and non-linear analysis that used to identify the behaviors of blocks under the static and dynamic loading.

For numerical modelling, non-linear stress strain model for confined and unconfined concrete was considered as per Mander et al [14]. It consists of simple stress strain curve with controlling parameters for modelling of steel reinforcement. The beam and column sectional elements were modeled as elastic elements with plastic hinges at ends of members. The plastic hinges represent the concentrated behavior of structural member during numerical analysis. Default hinges characteristic used for the concrete sections was based on FEMA-356 [15] and ATC-40 [16] criteria. Flexural default hinge (M3) was assigned both ends of beams member and columns interacting (P-M2-M3) frame hinge type a coupled hinge property was assigned both lower and upper end of the member.

\subsection{Nonlinear Static Analysis}

In the recent years, non-linear static analysis gains the popularity among the researchers due to its simplicity and validity. Pushover analysis is conducted to estimate the strength and displacement capacity of existing structures [17]. Several international seismic guidelines proposed the standard procedures for pushover analysis $[15,16]$. Generally, displacement controlled and force-controlled methods are used during pushover analysis. In the present study, displacement-controlled method was used for numerical analysis. During analysis, the building model was subjected to gravity load and monotonic displacement controlled lateral load patten in a seismic force continuously increasing from elastic to plastic behaviors of structure until the targeted displacement is exceeded. Target displacement of building is maximum 
displacement of top floor level that was determined by standard guidelines [15-16]. The following steps were followed during analysis in:

- create 3-D models of study institutional buildings

- apply dead and live load on a numerical model

- define plastic hinge properties on beam column element assuming $10 \%$ relative distance

- apply the displacement on the top storey of structure whose value is large than those associated with target displacement

- develop tables of roof displacement verse base shear or pushover curve

\subsection{Time History Analysis:}

The study of dynamic response of building structure behaviors under the specific loading (past earthquake) that may vary with time is known as time history analysis. The analysis was used to compute response of structure at a number of subsequent time instants. For the time history analysis, a representative Gorkha earthquake time history recorded at Kantipath used to evaluate structure response. Linear time history analysis compute the solution of dynamic equilibrium equation of building structure behaviors at given arbitrary time. The main purpose of linear time history analysis was to estimate displacement demand of building structure response in terms of top storey displacement.

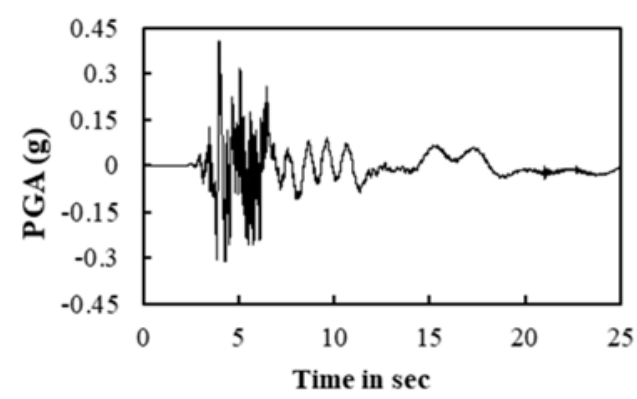

Figure 1: Time history plot of 2015 Gorkha earthquake in Nepal

To calculate structure demand parameter, it is necessary to determine the behavior of structures using the earthquake recorded data. In this study, synthetic earthquake data that consist of a simulated ground motion time history of Gorkha earthquake was used. An appropriate set of acceleration was required for dynamic analysis of structure [18].

The earthquake data has compatible with elastic design response spectrum of this region [19]. First synthetic/artificial accelerograms were purposed by Gasparini and Vanmarke [20] which was based on design response spectrum. The time history data used in this study is presented given in Table 1, while the records are shown in Fig. 1.

Table 1: Time history data used for dynamic analysis

\begin{tabular}{cc}
\hline $\begin{array}{c}\text { Name of } \\
\text { Earthquake }\end{array}$ & $\begin{array}{c}\text { Peak Ground } \\
\text { Acceleration (PGA) }\end{array}$ \\
\hline \hline Gorkha earthquake & $0.4 \mathrm{~g}$ \\
\hline \hline
\end{tabular}

\section{Case Study:}

\subsection{Building Model:}

In this study, one of the school building of Pokhara University Nepal (School of Health and Allied Science, SHAS) was considered as a study building (see Fig. 2). The building is situated in Pokhara Metropolitan City, 30. The institutional building consists of three parts: left portion before the expansion joint is called block A, mid portion between two expansion joints is called block B and right portion after expansion joint is called block C (see Fig. 3-5). In this study, the response of the building can be observed by block wise.

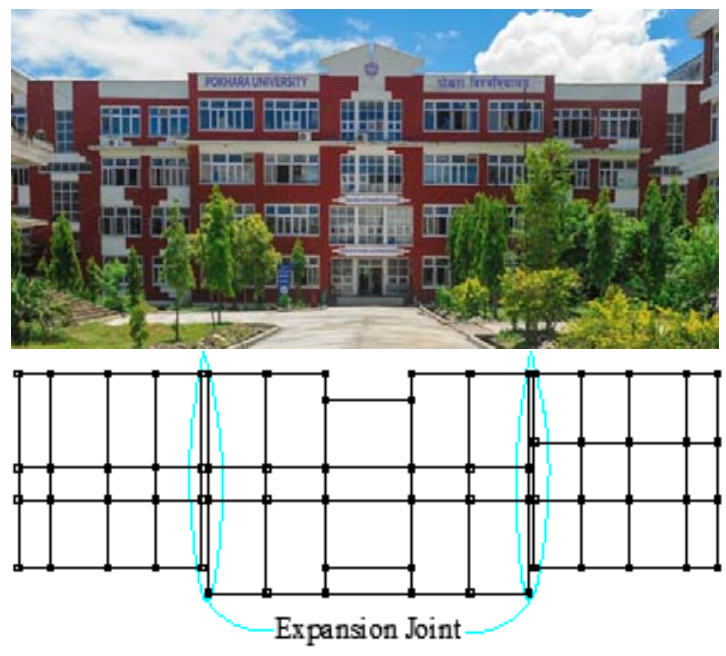

Figure 2: (a) Existing SHAS building and (b) Plan of SHAS building

Building block $\mathrm{A}, \mathrm{B}$ and $\mathrm{C}$ measures $14.1 \mathrm{~m}$ $\times 14.8 \mathrm{~m}, 24.6 \mathrm{~m} \mathrm{x} 16.8 \mathrm{~m}$ and $14.1 \mathrm{~m} \times 14.8 \mathrm{~m}$ in 
$\mathrm{x}$ and $\mathrm{y}$ direction, respectively. All the building blocks have storey height of $3.3 \mathrm{~m}$ and slab thickness $150 \mathrm{~mm}$. Block A comprises five moment resisting frame in $x$ and four moment resisting frame in $y$ direction. Similarly, block B have six moment resisting frame in $x$ and four moment resisting frame in $y$ directions but in middle portion, one additional structural frame was inserted. Likewise, in building block $\mathrm{C}$, five moment resisting frame in $x$ direction and four moment resisting frame in $y$ direction. The plan and 3D of the study building blocks structures are presented in Fig. 3-5. The details present of beam and column size and its reinforcement are in Table 2.

Table 2: Building section properties

\begin{tabular}{|c|c|c|c|c|c|c|}
\hline \multicolumn{3}{|c|}{ Beam } & \multicolumn{3}{|c|}{ Column } & \multirow{2}{*}{ Slab } \\
\hline Section & Size $(\mathrm{mm})$ & Rebar & Section & Size $(\mathbf{m m})$ & Rebar & \\
\hline \multirow{2}{*}{ B1 } & \multirow{2}{*}{$300 \times 500$} & $3 \varnothing 25$ & \multirow{2}{*}{$\mathrm{C} 1-\left(\mathrm{G} . \mathrm{F} \& 1^{\text {st }}\right.$ floor $)$} & \multirow{2}{*}{$400 \times 450$} & $4 \varnothing 20$ & \multirow{16}{*}{$\begin{array}{l}150 \mathrm{~mm} \\
\text { Thickness }\end{array}$} \\
\hline & & $3 \varnothing 20$ & & & $4 \varnothing 16$ & \\
\hline \multirow{2}{*}{ B2 } & \multirow{2}{*}{$300 \times 500$} & $4 \varnothing 20$ & \multirow{2}{*}{ C2- (G.F \& $1^{\text {st }}$ floor) } & \multirow{2}{*}{$400 \times 450$} & $4 \varnothing 20$ & \\
\hline & & $3 \varnothing 20$ & & & $8 \varnothing 16$ & \\
\hline \multirow{2}{*}{ B3 } & \multirow{2}{*}{$300 \times 500$} & $5 \varnothing 20$ & \multirow{2}{*}{ C3- (G.F \& $1^{\text {st }}$ floor $)$} & \multirow{2}{*}{$400 \times 450$} & $4 \varnothing 25$ & \\
\hline & & $3 \varnothing 20$ & & & $4 \varnothing 20$ & \\
\hline B4 & $300 \times 500$ & $\begin{array}{l}3 \varnothing 20 \\
3 \varnothing 20\end{array}$ & C4- (G.F \& $1^{\text {st }}$ floor) & $400 \times 450$ & $8 \varnothing 20$ & \\
\hline \multirow{2}{*}{ B5 } & \multirow{2}{*}{$300 \times 350$} & $5 \varnothing 20$ & \multirow{2}{*}{ C5- (G.F \& $1^{\text {st }}$ floor $)$} & \multirow{2}{*}{$400 \times 450$} & $8 \varnothing 16$ & \\
\hline & & $4 \varnothing 20$ & & & 8010 & \\
\hline B6 & $300 \times 350$ & $\begin{array}{l}4 \varnothing 20 \\
3 \varnothing 20\end{array}$ & $\mathrm{C} 1-\left(2^{\text {nd }} \& 3^{\text {rd }}\right.$ floor $)$ & $400 \times 450$ & $8 \varnothing 16$ & \\
\hline B7 & $300 \times 350$ & $\begin{array}{l}5 \varnothing 20 \\
3 \varnothing 20\end{array}$ & $\mathrm{C} 2-\left(2^{\text {nd }} \& 3^{\text {rd }}\right.$ floor $)$ & $400 \times 450$ & $12 \varnothing 16$ & \\
\hline \multirow[t]{2}{*}{ B8 } & \multirow[t]{2}{*}{$300 \times 350$} & $6 \varnothing 20$ & $\mathrm{C} 3-\left(2^{\text {nd }} \& 3^{\text {rd }}\right.$ floor $)$ & $400 \times 450$ & $4 \varnothing 25$ & \\
\hline & & $\begin{array}{l}3 \varnothing 20 \\
5 \varnothing 20\end{array}$ & & & $\begin{array}{l}4 \varnothing 16 \\
4 \varnothing 20\end{array}$ & \\
\hline B9 & $300 \times 600$ & $3 \varnothing 20$ & C4- $\left(2^{\text {nd }} \& 3^{\text {rd }}\right.$ floor $)$ & $400 \times 450$ & $4 \varnothing 16$ & \\
\hline B10 & $300 \times 600$ & $6 \varnothing 20$ & $\mathrm{C} 5-\left(2^{\text {nd }} \& 3^{\text {rd }}\right.$ floor $)$ & $400 \times 450$ & $4 \varnothing 16$ & \\
\hline Div & $500 \times 000$ & $3 \varnothing 20$ & $(3-(2-28511001)$ & $400 \times 450$ & $4 \varnothing 12$ & \\
\hline
\end{tabular}

\subsection{Material Properties:}

To identify behaviors of the structure, several material properties should be taken. The material properties of rebar and compressive strength of concrete were taken from experimental testing and blue print of existing drawing. The yield strength of rebar for all building blocks were adopted as $415 \mathrm{MPa}$. Schmidt hammer test is a non-destructive testing method that was performed to identify the compressive strength of concrete. Some specific material properties from experimental testing and blue print of existing drawing is tabulated in Table 3. During modelling, weight of infill wall was considered but stiffness of the masonry wall was ignored. Similarly, dead load was calculated as per drawing specified and live load was adopted as per IS-875 Part-II [21]. The live load in corridors, passages, staircase taken as $4 \mathrm{kN} / \mathrm{m}^{2}$. Similarly, live load in class room, store and bathroom taken as $3 \mathrm{kN} / \mathrm{m}^{2}, 5 \mathrm{kN} / \mathrm{m}^{2}$ and $2 \mathrm{kN} / \mathrm{m}^{2}$, respectively.

Table 3: Concrete material properties of building.

\begin{tabular}{cc}
\hline Properties & Values \\
\hline Elastic modulus & $19364.92 \mathrm{MPa}$ \\
Shear modulus & $8068.72 \mathrm{MPa}$ \\
Weight density & $25 \mathrm{kN} / \mathrm{m} 3$ \\
Poisson's ratio & 0.2 \\
\hline
\end{tabular}




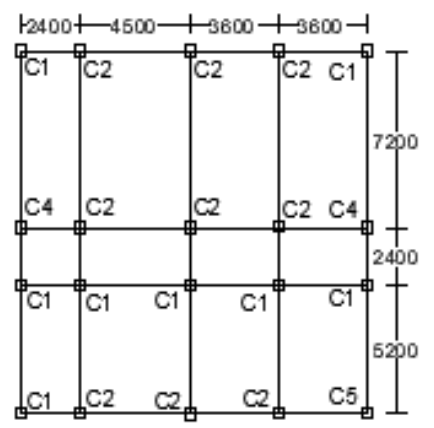

(a)

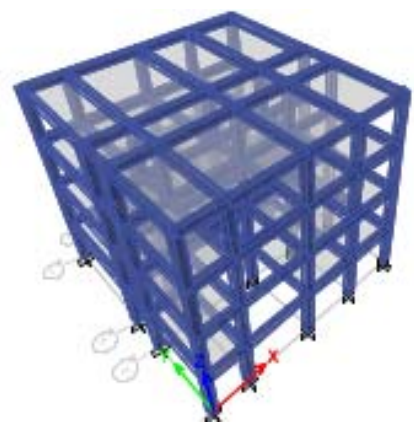

(b)

Figure 3: Block A building model (a) Plan and (b) 3D view

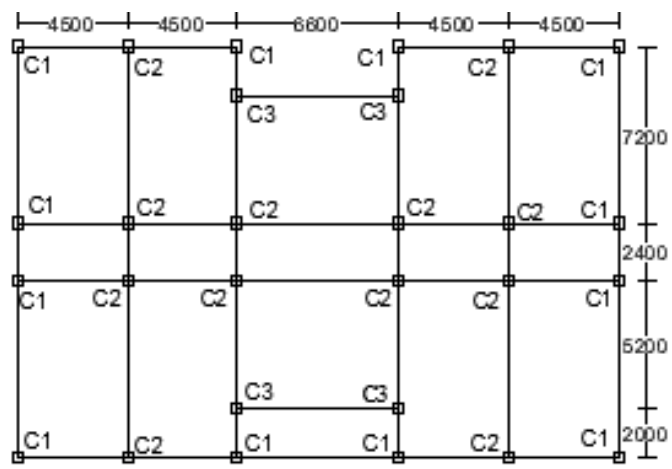

(a)

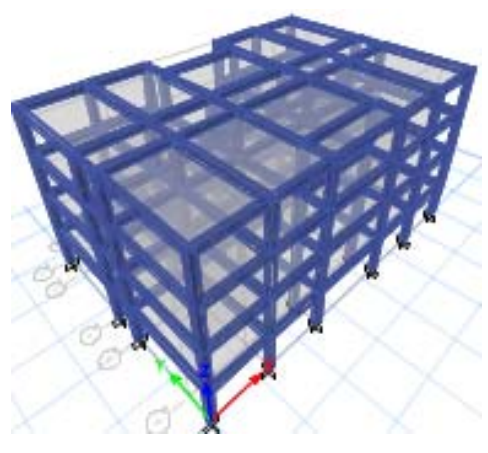

(b)

Figure 4: Block B building model (a) Plan and (b) 3D view

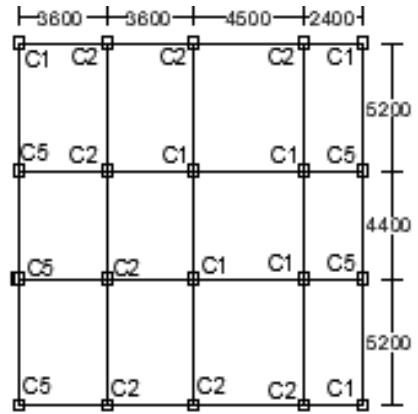

(a)

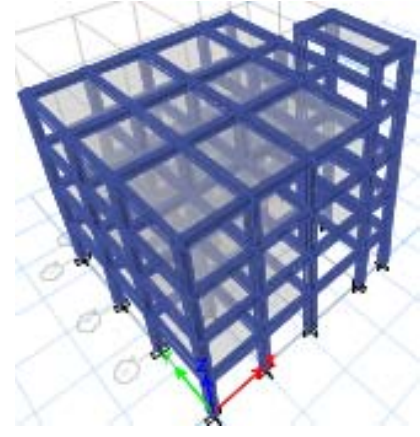

(b)

Figure 5: Block C building model (a) Plan and (b) 3D view 
4. Result and Discussion:

\subsection{Fragility Analysis:}

To derive the fragility curve from cumulative probability of failure correlate with increasing the demand displacement value (Sd) based on best fitted log-normal distribution function of equation that defined by median $(S c)$ and standard deviation parameters $(\beta)$. The equation of probability of failure is defined as a function of Sd:

$$
P(f)=\varnothing\left[\frac{\ln (S d / S c)}{\beta}\right]
$$

Where, $\varnothing($ ) stands for standard normal cumulative distribution function, $S d$ be the demand displacement and $S c$ and $\beta$ be the medium of damage state value and standard deviation that represent total uncertainty. It is simply square root sum of the square's combination of individual variability terms which is equivalent to 0.64 from HAZUS table [22].

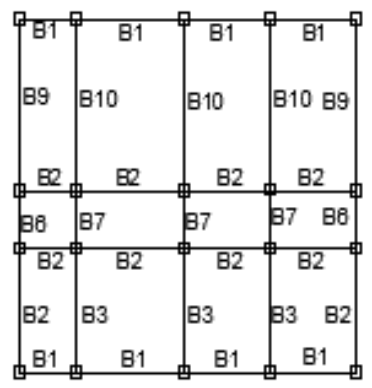

(a)

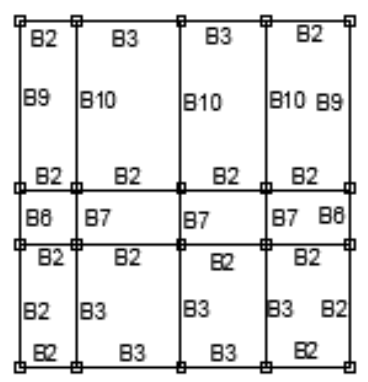

(d)

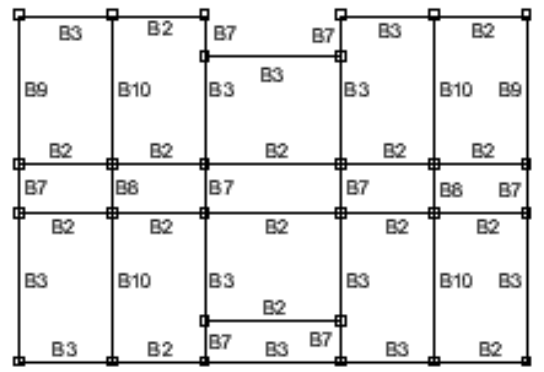

(b)

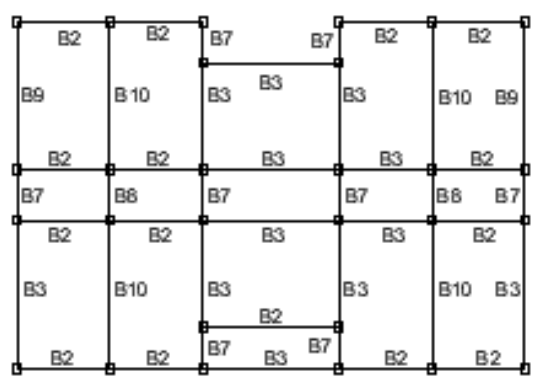

(e)

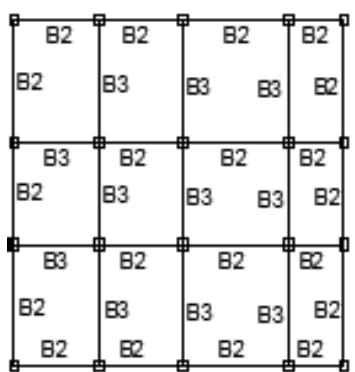

(c)

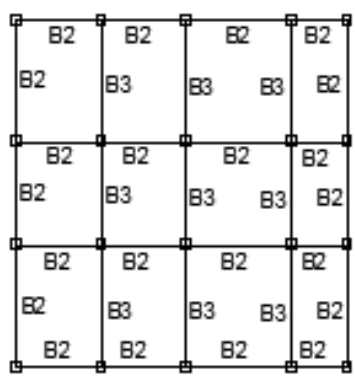

(f)

Figure 6: Floor beam layout (a) Block A 1st floor, (b) Block B 1st floor, (c) Block C 1st floor, (d) Block A 2nd 3rd 4th floors (e) Block B 2nd 3rd 4th floors (f) Block C 2nd 3rd 4th floors.

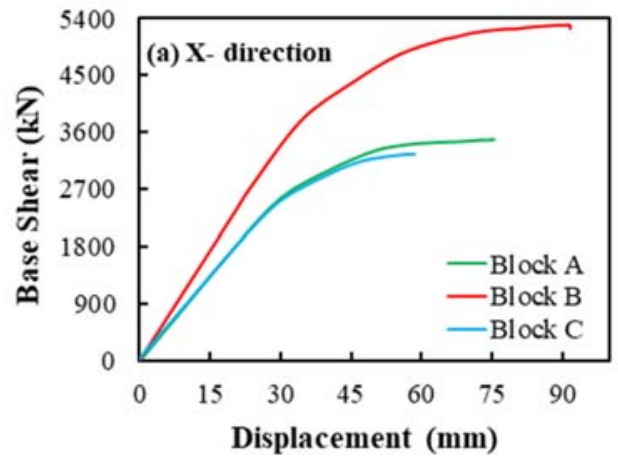

(a)

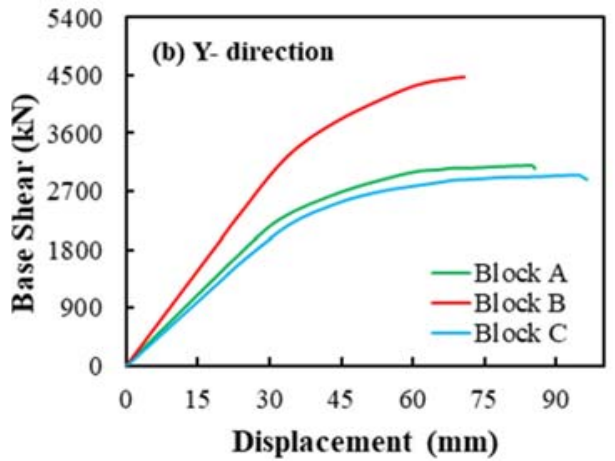

(b)

Figure 7: Pushover curve of Block A, B and C with (a) X-direction and (b) Y-direction

Demand displacement was estimated by linear time history analysis of Gorkha earthquake.
Medium of damage states were estimated based on yield and ultimate displacement proposed by 
Giovinazzi and Lagomarsino [12]. Idelization of capacity curve gives yield displacement $(d y)$ and ultimate displacement $(d u)$ of building structure. The following damage states used to describe performance levels of building structure.

- Slight damage $=0.7 d y$

- Moderate damage $=1.5 d y$

- Extensive damage $=0.5(d y+d u)$

- Complete damage $=d u$

Table 4: Probability of failure of building

\begin{tabular}{ccccc}
\hline $\begin{array}{c}\text { Building } \\
\text { (Block) }\end{array}$ & $\begin{array}{c}\text { Slight } \\
(\%)\end{array}$ & $\begin{array}{c}\text { Mod } \\
\text { erate } \\
\text { (\%) }\end{array}$ & $\begin{array}{c}\text { Exte } \\
\text { nsive } \\
(\%)\end{array}$ & $\begin{array}{c}\text { Complete } \\
\text { (\%) }\end{array}$ \\
\hline \hline A & 98 & 85.6 & 83 & 67.6 \\
B & 97.9 & 80.2 & 77.4 & 60.2 \\
C & 98.8 & 85.5 & 81.1 & 63.8 \\
\hline \hline
\end{tabular}

Fragility curves are constructed with four damage states that represent probability of failure from 0 to 1 corresponding to peak ground acceleration from $0-1$ g. Fig. 8 indicates the fragility curves of study building models which help engineer/decision maker to assure the seismic vulnerability condition of the structure and to predict the damage of building structure from possible future earthquake. Seismic hazard map of Nepal proposed by Parajuli [23] indicates that PGA value of Pokhara for $10 \%$ probability of exceedence in 50 years was expected to be $0.4 \mathrm{~g}$. So, probability of failure of building at different damage state was observed at $0.4 \mathrm{~g}$ PGA.

From Fig. 8, it can be seen that building block A has probability of failure in slight damage will be quite high, approximately $98 \%$. Whereas moderate, extensive and complete damage found as approximate $85.6 \%, 83 \%$ and $67.6 \%$, respectively. Similarly, building block B indicates that slight damage of building is higher as compared with other damage state. Slight, moderate, extensive and complete damage was estimated $97.9 \%, 80.2 \%, 77.4 \%$ and $60.2 \%$ respectively. In block $\mathrm{C}$ building model; slight, moderate, extensive and complete damage state was estimated $98.8 \%, 85.5 \%, 81.1 \%$ and 63.8 $\%$, respectively. The above discussion result concluded that building performance levels depends upon the probability of failure of each damage state, if higher probability of failure of damage states less performance levels of buildings. Finally, more than $50 \%$ damage state was estimated of all building block are present in Table 4.

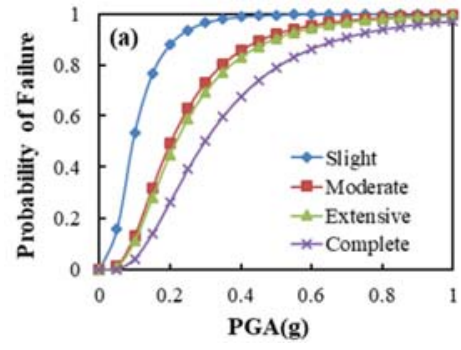

(a)

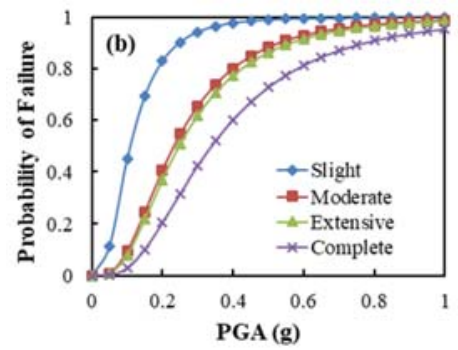

(b)

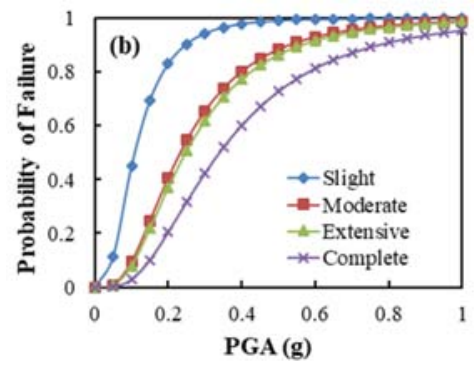

(c)

Figure 8: Fragility curves (a) block A, (b) block B and (c) block C

\section{Conclusions:}

The study focused to construct the fragility curve of RC institution building. For this, RC institutional building in Pokhara University (SHAS) was considered as case study. For obtaining fragility curve linear and non-linear analyses were performed with finite element software. Fragility curves were plotted with the probability of failure at every $0.1 \mathrm{~g}$ interval of PGA that used to estimate building structure damage/performance levels under the effect of potential earthquake. The conclusions of analytical fragility curve can be summarized as:

- Seismic fragility curve of all the building models are constructed with four damage state (slight, moderate, extensive and complete). An increase in PGA leads to an increased fragility.

- Fragility curve of building depends upon building properties and configuration but not an earthquake data. 
- The slope of the fragility curve was large at lower PGA and smaller at higher PGA. Finally, more than $50 \%$ of all damage states were found at $0.4 \mathrm{~g}$ PGA value which concluded that a building was low performance level at 475 years return period of earthquake.

\section{References:}

[1] H. Chaulagain, H. Rodrigues, V. Silva, E. Spacone and H. Varum, "Earthquake loss estimation for the Kathmandu Valley," Bulletin of Earthquake Engineering, vol. 14, no. 1, pp. 59-88, Sept. 2015. https://doi.org/10.1007/s10518-0159811-5

[2] M.R. Pandey, R.P. Tendukar, J.P. Avouac, J. Lave and J.P. Massot, "Interseismic Strain Accumulation on the Himalayan Crustal," Geophysical Research Letters, vol 22, pp. 751-754, 1995.

[3] H. Chaulagain, H. Rodrigues, V. Silva, E. Spacone and H. Varum, " Seismic risk assessment and hazard mapping in Nepal," Natural Hazards, vol. 78, pp. 583602 , 2015.

https://doi.org/10.1007/s11069-0151734-6

[4] R. Adhikari and D. Gautam, "Component level seismic fragility functions and damage probability matrices for Nepali school buildings," Soil Dynamics and Earthquake Engineering, vol. 120, pp. 316-319, $\quad$ Feb. 2019. https://doi.org/10.1016/j.soildyn.2019.02. 009

[5] H.K. Miyamoto, A.S. Gilani and A. Wada, "Damage mitigation for school buildings in seismically vulnerable regions," International Journal of Disaster Resilience in the Built Environment, 2011.

https://doi.org/10.1108/17595901111108 344

[6] N. Augenti, E. Cosenza, M. Dolce, G. Manfredi, A. Masi and L. Samela, "Performance of school buildings during the 2002 Molise, Italy, earthquake," Earthquake Spectra, vol. 20, pp. 257-270, 2004. https://doi.org/10.1193/1.1769374

[7] J. Kirk, "Building back better: postearthquake responses and educational challenges in Pakistan," International Inst for Educational Planning, 2008.

[8] C.C. Neupane, N. Anwar and S. Adhikari, "Performance of school buildings in Gorkha earthquake 2015, The 7th Asia conference on earthquake engineering, $\mathrm{pp}$. 22-25, 2018.

[9] D. Gautam, R. Adhikari, R. Rupakhety and P. Koirala, "An empirical method for seismic vulnerability assessment of Nepali school buildings," Bulletin of Earthquake Engineering, pp. 1-18, Aug. 2020. https://doi.org/10.1007/s10518020-00922-z

[10] N. Ahmad, A. Shahzad, Q. Ali, M. Rizwan and A.N. Khan, "Seismic fragility functions for code compliant and noncompliant RC SMRF structures in Pakistan," Bulletin of Earthquake Engineering, vol. 16, no. 10, pp. 46754703, Apr. 2018. https://doi.org/10.1007/s10518-0180377-x

[11] G. M. Calvi, R. Pinho, G. Magenes, J.J. Bommer, L.F. Restrepo-Vélez and H. Crowley, " Development of seismic vulnerability assessment methodologies over the past 30 years," ISET journal of Earthquake Technology, vol. 43, no. 3, pp. 75-104, Sept. 2006.

[12] S. Lagomarsino and S. Giovinazzi, "Macroseismic and mechanical models for the vulnerability and damage assessment of current buildings," Bull of Earthquake Engineering, vol. 4, no. 4, pp. 415-443, 2006. https://doi.org/10.1007/s10518-0069024-z

[13] ETABS, Computers and Structures, INC, 2016. <https://www.csiamerica.com>.

[14] J.B. Mander, M.J. Priestley and R. Park, "Theoretical stress-strain model for confined concrete," Journal of structural 
engineering, vol. 114, no. 8, pp. 18041826 , 1988.

https://doi.org/10.1061/(ASCE)07339445 (1988)114:8(1804)

[15] FEMA-356, "Prestandard and commentary for the seismic rehabilitation of buildings," Federal Emergency Management Agency, American Socity of Civil Engineers, Washington, D.C, 2000.

[16] ATC 40, "Seismic evaluation and rectrofit of concrete buildings," Aplied Technical Council, Seismic safety Commission, Redwood City, California, 1996.

[17] H. Chaulagain, H. Rodrigues, E. Spacone and H. Varum, "Seismic response of current RC buildings in Kathmandu Valley," Structural Engineering and Mechanics, vol. 53, no. 4, pp. 791-818, Feb.

2015.

http://dx.doi.org/10.12989/sem.2015.53.4 .791

[18] Y.M. Fahjan, "Selection and scaling of real earthquake accelerograms to fit the Turkish design spectra," Teknik Dergi, vol. 19, no. 3, pp. 4423-4444, 2008.
[19] H. Chaulagain, H. Rodrigues, H. Varum, V. Silva and D. Gautam, "Generation of spectrum-compatible acceleration time history for Nepal," Comptes Rendus Geoscience, vol. 349, no. 5, pp.198-201, Aug. http://dx.doi.org/10.1016/j.crte.2017.07.0 01

[20] D. Gasparini and E.H.Vanmarc, "SIMQKE: A program for artificial motion generation," Department of Civil Engineering, Massachusetts Institute of Technology, Cambridge, MA, 1976.

[21] IS 875-II, "Code of Practice for Design Loads (Other Than Earthquake) For Buildings And Structures, Part 2: Imposed Loads," New Delhi, Mar. 1987.

[22] HAZUS-MH-MR4, "Multi-hazard Loss Estimation Methodology," Department of Homeland Security, Emergency Preparedness and Response Directorate, Federal Emergency Management Agency, Washington, D.C, 2004.

[23] HR. Parajuli, "Dynamic analyses of low strength masonry houses based on site specific earthquake ground motions" 2009 